\title{
THIOFLAVIN T BINDING TO THE MODEL FIBRILS OF LYSOZYME: THE EFFECTS OF FIBRIL TWISTING
}

\author{
A.E. Kokorev, V.M. Trusova, K.O. Vus, U.K. Tarabara, G.P. Gorbenko \\ Department of Nuclear and Medical Physics, V.N. Karazin Kharkiv National University \\ 4 Svobody Sq., Kharkiv, 61022, Ukraine \\ e-mail: valerija.trusova@karazin.ua \\ Received 24 October, 2017
}

Amyloid fibrils are highly ordered insoluble protein aggregates that are involved in molecular etiology of a number of severe disorders, including Alzheimer's, Parkinson's and prion's diseases, some types of systemic amyloidosis, etc. One of the most effective approaches to detecting the amyloid fibrils is based on monitoring the spectral behavior of specific fluorescent dye Thioflavin T (ThT). Using the molecular docking and molecular dynamics tools, such as PatchDock, FireDock, CreateFibril and GROMACS, the model of twisted K-peptide fibril that supposedly represent the core region of lysozyme amyloid fibrils, has been constructed and analyzed. The effect of fibril twisting angle on the binding characteristics of ThT has been evaluated. The results obtained strongly suggest that ThT specificity for the twisted ribbon fibril polymorphs is primarily determined by the curvature effects rather than amino acid composition of fibril grooves which accomodate ThT molecule.

KEYWORDS: amyloid fibrils, Thioflavin T, molecular docking, molecular dynamics, fibril twisting

\section{ЗВ'ЯЗУВАННЯ ТІОФЛАВІНУ Т З МОДЕЛЬНИМИ ФІБРИЛАМИ ЛІЗОЦИМУ: ЕФЕКТ ЗАКРУЧУВАННЯ ФІБРИЛ}

А.Е. Кокорєв, В.М. Трусова, К.О. Вус, У.К. Тарабара, Г.П. Горбенко

Кафедра ядерної та медичної фізики, Харківський національний університет імені В.Н. Каразіна пл. Свободи 4, Харків, 61022, Україна

Амілоїдні фібрили - це високо впорядковані нерозчинні білкові агрегати, які викликають цілу низку серйозних захворювань, таких як хвороби Альцгеймера та Паркінсона, пріонні патології, деякі типи системного амілоїдозу, тощо. Один із найбільш ефективних підходів до детектування амілоїдних фібрил базується на дослідженні спектральної поведінки специфічного флуоресцентного барвника, Тіофлавіну Т (ThT). За допомогою методів молекулярного докінгу та молекулярної динаміки, з використанням програмних пакетів PatchDock, FireDock, CreateFibril та GROMACS, була створена та проаналізована модель закрученої фібрили К-пептиду, який, вірогідно, входить до ядра амілоїдних фібрил лізоциму. Було досліджено вплив кута закручування фібрил на їх зв'язування з ThT. Отримані результати свідчать про те, що специфічність ThT до закручених фібрил переважно визначається ефектами кривизни, а не амінокислотним складом фібрилярних жолобків, в яких розташовується молекула ThT.

КЛЮЧОВІ СЛОВА: амілоїдні фібрили, Тіофлавін Т, молекулярний докінг, молекулярна динаміка, закручування фібрил

\section{СВЯЗЫВАНИЕ ТИОФЛАВИНА Т С МОДЕЛЬНЫМИ ФИБРИЛЛАМИ ЛИЗОЦИМА: ЭФФЕКТ ЗАКРУЧИВАНИЯ ФИБРИЛЛ}

А.Е. Кокорев, В.М. Трусова, Г.П. Горбенко, К.А. Вус, У.К. Тарабара

Кафедра ядерной и медицинской физики, Харьковский национальный университет имени В.Н. Каразина пл. Свободы 4, Харьков, 61022, Украина

Амилоидные фибриллы - это высокоупорядоченные нерастворимые белковые агрегаты, которые вызывают целый ряд серьезных заболеваний, таких как болезни Альцгеймера и Паркинсона, прионные заболевания, некоторые типы системного амилоидоза и т.д. Один из наиболее эффективных подходов к детектированию амилоидных фибрилл базируется ни исследовании спектрального поведения специфичного флуоресцентного красителя, Тиофлавина Т (ThT). С помощью методов молекулярного докинга и молекулярной динамики, используя программные пакеты PatchDock, FireDock, CreateFibril и GROMACS, была создана и проанализирована модель закрученной фибриллы К-пептида, который, вероятно, входит в ядро амилоидных фибрилл лизоцима. Было изучено влияние угла закручивания фибрилл на их связывание с ThT. Полученные результаты свидетельствуют о том, что специфичность ТhT к закрученным фибриллам преимущественно определяется эффектами кривизны, а не аминокислотным составом фибриллярных желобков, в которых располагается молекула ThT.

КЛЮЧЕВЫЕ СЛОВА: амилоидные фибриллы, Тиофлавин Т, молекулярный докинг, молекулярная динамика, закручивание фибрилл

Amyloid fibrils are highly ordered insoluble protein aggregates which are formed in a process of one-dimensional crystallization of polypeptide chains. This class of protein self-assemblies is currently in the focus of extensive research efforts due to at least two aspects. First, the formation of amyloid fibrils and their subsequent accumulation in different tissues and organs is associated with the development of a wide range of debilitating disorders, including Parkinson's, Alzheimer's, Huntington's, Creutzfeldt-Jakob diseases, type II diabetes, bovine spongiform encephalopathy, etc. [1]. Second, amyloid fibrils are regarded as prospective nanomaterials distinguished by superior physicochemical and mechanical properties, among which are high elasticity, rigidity, thermal and chemical stability, biocompatibility, etc. [2]. Another interesting feature of amyloid fibrils involves their structural polymorphism, i.e. the ability to form various (C) Kokorev A.E., Trusova V.M., Vus K.O., Tarabara U.K., Gorbenko G.P., 2017 
spatial structures (helical ribbons, twisted ribbons, nanotubes). The particular fibril conformation is defined by the parameters, such as chirality, electrostatic repulsion, elastic properties and entropy penalty arising from the solvation of the side groups and backbone of polypeptide chain $[3,4]$.

One of the most effective approaches to detecting the amyloid fibrils is based on the use of specific fluorescent dye ThT. The main advantages of this dye include dramatic (about a few orders of magnitude) increase of fluorescence intensity and shift of the excitation maximum upon fibril binding. The mode of ThT binding to amyloid fibrils depends on a number of factors, particularly, on the physicochemical characteristics of the amyloid fibers and their structural peculiarities.

The aim of the present study was to evaluate the effect of such structural parameter as fibril twisting angle on the binding of ThT to the model fibrils constructed from the K-peptide (GILQINSRW) which represents the core region of hen egg white lysozyme (HEWL) amyloid fibers [2]. To achieve this goal, the methods of molecular docking and molecular dynamics have been utilized.

\section{MATERIALS AND METHODS}

The construction of ThT-fibril complex included several steps:

1) Design of K-peptide monomer in ABALONE on a basis of its amino acid sequence (GILQINSRW) in the extended conformation.

2) Molecular docking of the monomers using PatchDock server to produce K-peptide dimer with two antiparallel beta-strands.

3) Construction of the twisted ribbon amyloid fibrils consisting of $20 \beta$-strands and differing in twisting angle ( 0 , 10, 20, 30 or 40 degrees) (Fig. 1), with the use of the computational framework of CreateFibril tool. The distances between $\beta$-strands were set at $5 \AA$, which corresponds to the experimental estimate $(\sim 4.7 \AA)[5]$.

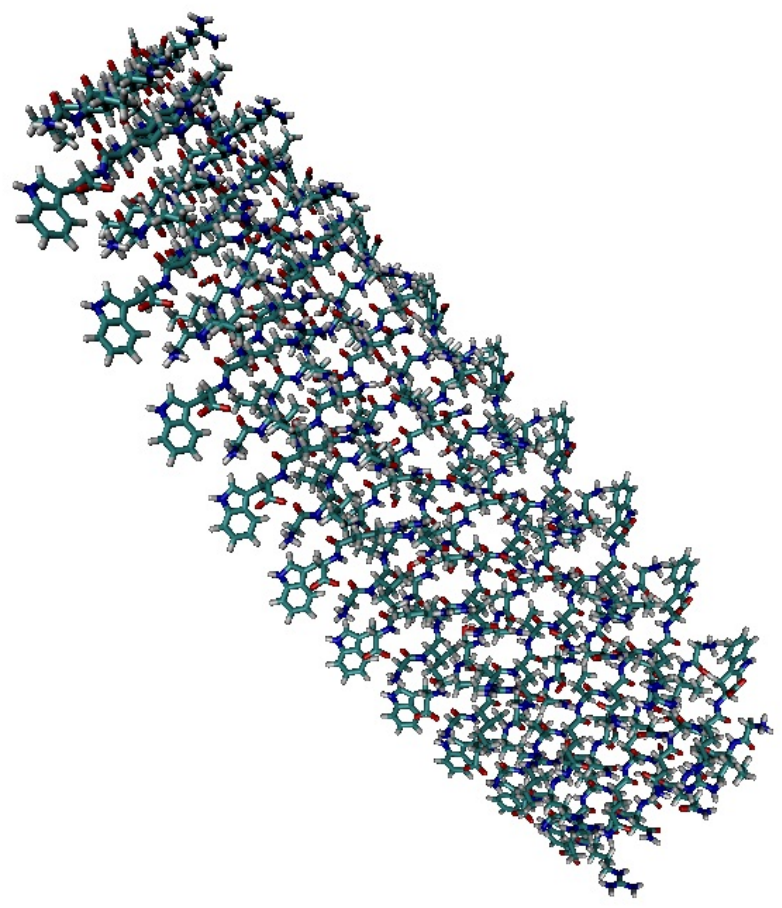

A

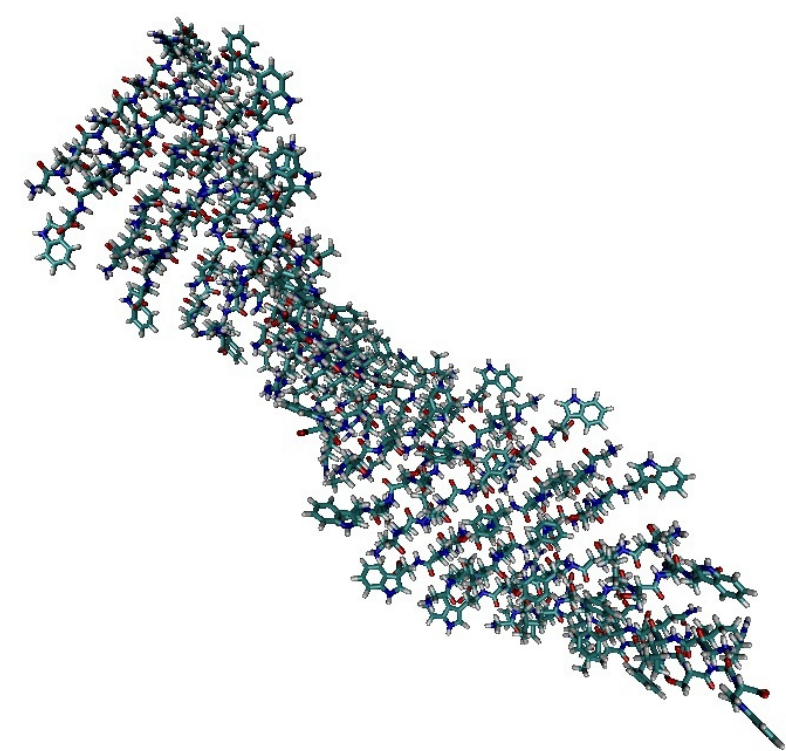

B

Fig. 1. The models of twisted ribbon fibrils made with CreateFibril script

(A) Twisting angle 10 degrees, view along twisting axis. (B) Twisting angle 30 degrees, view from the side

4) Molecular docking of K-peptide with ThT using the web servers PatchDock and FireDock. Ten best structures for each twisting angle and mutation were taken for subsequent analysis. For the sake of illustration, the representative structures are given in Fig. 2.

5) Molecular dynamics simulation of ThT - fibril system over $10 \mathrm{~ns}$ to analyze the structure and stability of the dye-protein complex. fibrils.

Given below is the brief overview of computational tools used in the present work for the analysis of the model

\section{PatchDock}

PatchDock is a free web server for geometrical protein-ligand docking [6]. The docking process is performed according to the one of the local shape feature matching algorithms. There are three main steps in this algorithm: 
1) Molecular Shape Representation. The molecular surface is computed and divided into geometrical patches of different types - convex, concave and flat.

2) Surface Patch Matching. The patches are matched in accordance with their type: concave with convex and flat with any other one.

3) Filtering and Scoring. The obtained complexes are verified, so that the structures containing steric clashes of receptor atoms with ligand atoms are discarded, while the remaining structures are sorted according to the geometric score function [7].
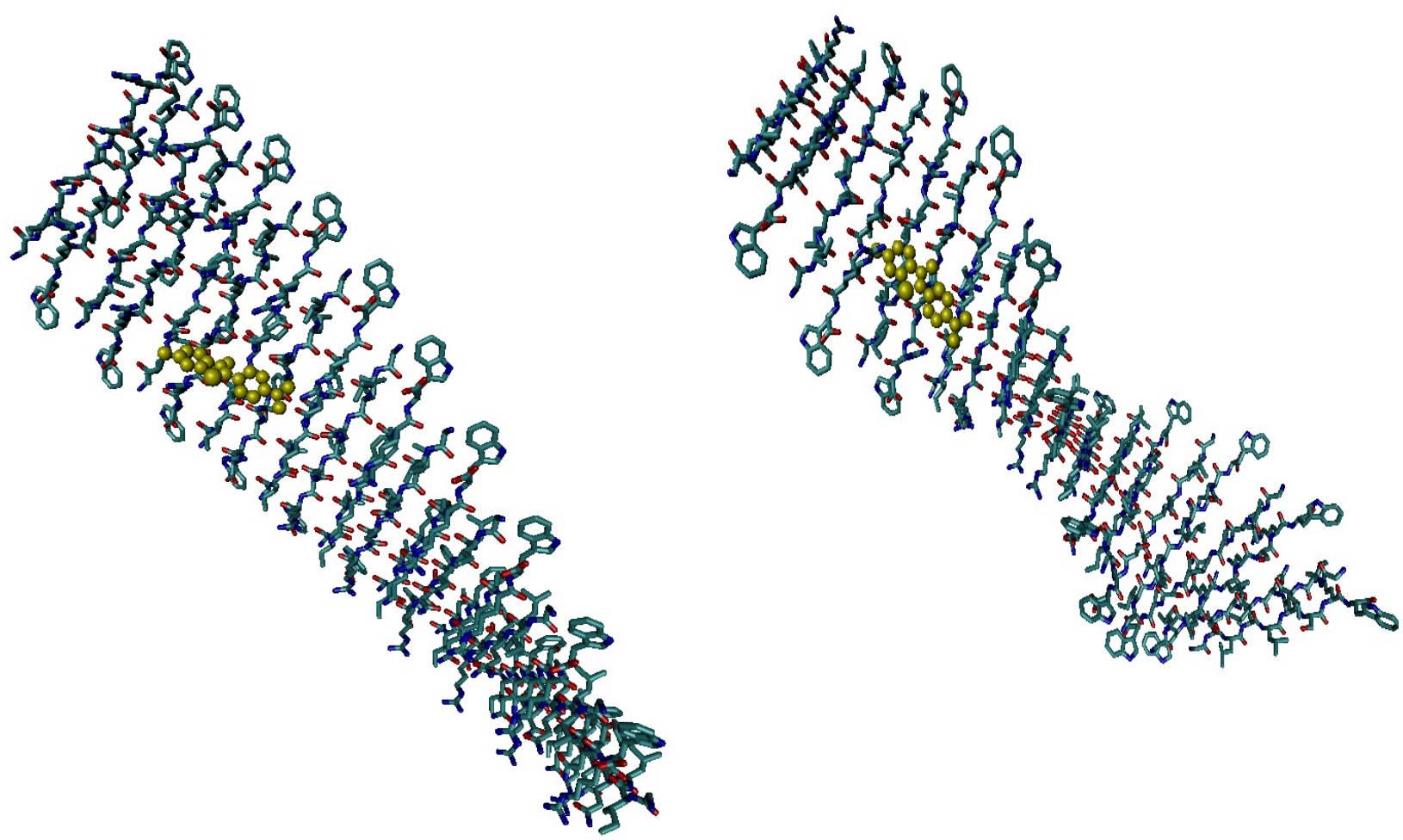

A

Fig. 2. ThT-fibril complex.

B

(A) Twisted angle 10. (B) Twisted angle 30. ThT molecule is located in the central groove QIN, perpendicular to the beta-strands.

\section{FireDock}

FireDock web server was developed in order to refine the structures, obtained after PatchDock matching. The algorithm is based on the calculation of the binding free energy function and includes three steps:

1) Interface side-chain optimization (ISCO). The flexibility of side chain is modeled using the rotamers of different probability taken from Dunbrack backbone-dependent rotamer library. Then the minimization of partial energy function $\left(E_{I S C O}\right)$ with van der Waals repulsion $\left(E_{V d W_{-} \text {rep }}\right)$ and rotamer $\left(E_{\text {rot }}\right)$ terms is performed.

$$
E_{\text {ISCO }}\left(i_{r}\right)=E_{V d W_{-} r e p}\left(i_{r}\right)+K E_{r o t}\left(i_{r}\right)
$$

where $i_{r}$ denotes rotamer $\mathrm{r}$ for residue $\mathrm{i}$, and $\mathrm{K}$ is a weight of rotamer's energy term.

The expressions for $E_{V d W_{-} r e p}$ (for atoms $\mathrm{a}_{\mathrm{i}}, \mathrm{a}_{\mathrm{j}}$ ) and $E_{\text {rot }}$ are given by:

$$
E_{V d W}\left(a_{i}, a_{j}\right)=\left\{\begin{array}{l}
e_{i j}^{\min }\left(\frac{\sigma_{i j}^{12}}{r_{i j}^{12}}-2 \frac{\sigma_{i j}^{6}}{r_{i j}^{6}}\right), \quad \text { for } r_{i j}>0.6 \sigma_{i j} \\
e_{i j}^{\min }\left(A+\left(r_{i j}-0.6 \sigma_{i j}\right) B, \quad \text { for } r_{i j} \leq 0.6 \sigma_{i j}\right.
\end{array},\right.
$$

here $e_{i j}^{\min }$ is a depth of potential well in CHARMM19 force field, $\sigma_{i j}$ is a sum of atomic radii and A, B are empirical constants. When $E_{V d W}$ value is positive, it corresponds to repulsive term, in the opposite case - to attractive one.

$$
E_{r o t}=-\log \frac{S\left(i, r, \phi_{i}, \psi_{i}\right)}{S\left(i, r_{u b}, \phi_{i}, \psi_{i}\right)}
$$

where $S\left(i, r, \phi_{i}, \psi_{i}\right)$ and $S\left(i, r_{u b}, \phi_{i}, \psi_{i}\right)$ are probabilities that the residue i with backbone angles $\phi_{i}, \psi_{i}$ is in a conformation $\mathrm{r}$, while $r_{u b}$ means unbound residue conformation.

2) Rigid-body minimization. The refinement of the orientation of the ligand and receptor as rigid bodies is 
performed on this step. It attempts to optimize the binding energy

$$
\mathrm{E}_{\mathrm{RBM}}=K E_{\text {soft_VdW_atr }}+E_{\text {soft_VlW_rep }} \text {, }
$$

where $E_{\text {soft_V } V d W_{-} \text {attr }}$ and $E_{\text {soft_ } V d W_{-} r e p}$ are the van der Waals soft attractive and repulsive terms, respectively, introduced to avoid backbone fluctuations during the binding process, calculated using Eq. (2) but with the decreased atomic radii, K is a relative weight of attractive term. By default, this step repeats 50 times, on each of which the quasi-Newton algorithm is executed.

3) Scoring and ranking. This step is required in order to find the near-native structures and separate them from the others structures. Thus, the optimization of binding energy with full set of terms, including atomic contact energy, van der Waals interactions, partial electrostatics, hydrogen and disulfide bonds, p-stacking and aliphatic interactions, rotamer's probabilities, etc., is performed. The resulting solutions are ranked by the calculated binding score, that strongly correlates with the actual binding energy (correlation coefficient $\sim 0.8)[7,8]$.

\section{CreateFibril}

The construction of a single fibril is based on the rotation of small part of fibril (1-2 $\beta$-strands) around a fibril long axis by twisting angle $\theta$ and its translation along this axis by a distance $d \AA$. These steps are performed by applying the transformation matrix $F_{\theta, d}$ to the set of atom coordinates obtained from the Protein Data Bank. The mathematical background of CreateFibril software involves the translational and rotational affine transformations which allow creating several identical copies of the fibril fragment and stacking them side-by-side, elongating thereby the fibrillar aggregate [9]. The procedure of the fibril constructing requires the following parameters: i) the number of protofilaments and their packing distance perpendicular to fibril axis, $n$ and $R$, respectively; ii) the direction of fibril axis; iii) the fibril length (the number of monomers), $r$; iv) the distance between $\beta$-strands along the fibril axis, $d$; v) the rotation angle of amyloid monomers along the fibril axis (twisting angle), $\theta$.

The main idea of this transformation is the following. The atoms of the first peptide are translated by the distance $d, \AA$ along the fibril axis by applying the translation matrix $T(d)$ to their coordinates. Next, a combination of translation and rotation matrixes $O(d, \mathrm{p}, \phi, \psi)$ is applied to transfer fibril axis (given by manually chosen point $p$ ) to the origin of coordinates and align it along the x-axis. After that, the rotation matrix $R_{x}(\theta)$ is used for rotation of the structure by the angle $\theta$ around the x-axis. After all, the reverse procedure $O^{-1}(d, \mathrm{p}, \phi, \psi)$ is performed in order to bring the whole protein molecule in an initial position. These steps can be expressed by the following expression:

$$
F_{\theta, d}=O^{-1}(d, \mathrm{p}, \phi, \psi) * R_{x}(\theta) * O(d, \mathrm{p}, \phi, \psi),
$$

where $\phi$ and $\psi$ are the angles by which one needs to rotate fibril axis in order to align it with the $\mathrm{x}$ axis. Finally, $R_{x}(\theta)$ is given by:

$$
R_{x}(\theta)=\left[\begin{array}{cccc}
1 & 0 & 0 & 0 \\
0 & \cos (\theta) & -\sin (\theta) & 0 \\
0 & \sin (\theta) & \cos (\theta) & 0 \\
0 & 0 & 0 & 1
\end{array}\right]
$$

\section{Molecular dynamics simulations}

The molecular dynamic simulation of ThT-fibril complex with zero twisting angle was performed using the GROMACS software (version 5.1) with the CHARMM36 force field. The quantum-chemical calculations in R.E.D. Server web interface were made to generate the topology of ThT molecule. In order to neutralize a positive charge of $\mathrm{ThT}$ molecule one $\mathrm{Cl}$ ion was added. The simulation was performed at physiological temperature $310 \mathrm{~K}$ in a cubic box filled with TIP3 water model during $10 \mathrm{~ns}$.

\section{RESULTS AND DISCUSSION \\ Molecular docking studies}

The first of the study involves the construction of the model amyloid fibrils of lysozyme, one of the amyloidogenic proteins, that in a human organism performs antitumor, antimicrobial and bactericidal functions [10]. It was reported that accumulation of the amyloid fibrils from the mutant forms of human lysozyme (mutations I56T, D67H, W64R), which represents the structural analogue of hen egg white lysozyme (HEWL), gives rise to such severe disorder as hereditary non-neuropathic systemic amyloidosis [11]. The central part of lysozyme amyloid fibrils has been hypothesized to be represented by the K-peptide (GILQINSRW), containing the amino acid residues 54-62 of HEWL [2]. For this reason, this peptide was used here for the construction of the model amyloid fibrils with different twisting angles using the CreateFibril software.

At the next step of the study, the model fibrils from the K-peptide were docked with ThT. The binding of ThT to 
the $\beta$-sheets, abundant in amyloid fibrils, is followed by characteristic $120 \mathrm{~nm}$ red shift of its excitation spectrum up to $450 \mathrm{~nm}$, resulting in a fluorescence maximum at $482 \mathrm{~nm}$. This unique property makes ThT an amyloid-specific probe [12]. One explanation for such specificity of ThT involves its peculiar location in amyloids. It has been proposed that ThT binds to fibrils via insertion into the channels (or grooves) formed between every other row of side chains, with the dye long axis being parallel to the fibril axis [2]. This results in a significant restriction of the dye mobility, and, as a consequence, the enhancement of its fluorescence by the orders of magnitude. It is supposed that specific accommodation of ThT within the amyloid fibril originates from the unique structure of this dye. Three main segments may be identified in the ThT structure: a benzthiazole ring (I), a benzene ring (II), and a dimethylamino group (III) (Fig. 3). It was shown, that photophysical properties of ThT strongly depend on the angle $\varphi$ between the planes in which segments I and II locate [13].

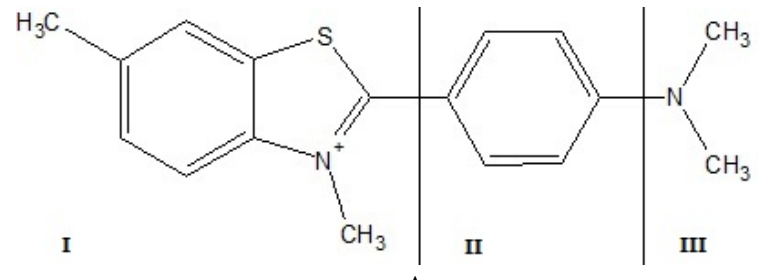

A

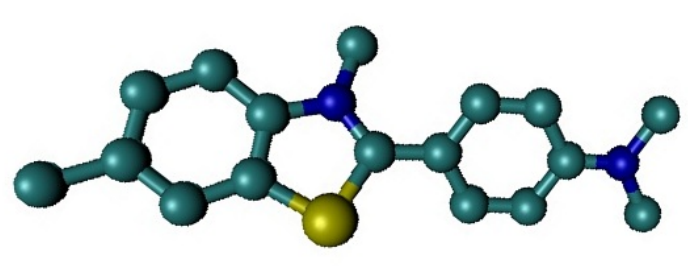

B

Fig. 3. The structure of Thioflavin T

(A) There are three molecular segments: benzothiazole ring (I), benzene ring (II), and dimethylamino group (III)

(B) 3D model of ThT

The binding energies characterizing the complexes between Thioflavin $T$ and twisted ribbon model fibrils differing in their twisting angle and the composition of the central groove

\begin{tabular}{|c|c|c|c|c|c|c|}
\hline \multirow{3}{*}{$\begin{array}{l}\text { Twisting } \\
\text { angle }\end{array}$} & \multicolumn{6}{|c|}{ Binding energy, $\mathrm{kcal} / \mathrm{mol}$} \\
\hline & \multicolumn{2}{|c|}{ Without mutation } & \multicolumn{2}{|c|}{$\mathrm{I} 6 \mathrm{E}$} & \multicolumn{2}{|c|}{ I6K } \\
\hline & QIN & GIL & QEN & GIL & QKN & GIL \\
\hline 0 & -20.92 & -25.27 & -30.51 & -27.24 & -23.11 & -38.17 \\
\hline 10 & -22.48 & - & -40.15 & -7.37 & -14.71 & -6.31 \\
\hline 20 & -14.58 & - & -12.95 & - & -26.47 & - \\
\hline 30 & -18.59 & - & -15.30 & - & -23.83 & - \\
\hline 40 & -10.28 & - & -14.87 & - & -14.87 & - \\
\hline \multirow{3}{*}{$\begin{array}{l}\text { Twisting } \\
\text { angle }\end{array}$} & \multicolumn{6}{|c|}{ Binding energy, kcal/mol } \\
\hline & \multicolumn{2}{|c|}{$\mathrm{I} 6 \mathrm{~F}$} & \multicolumn{2}{|c|}{ I6K } & \multicolumn{2}{|c|}{ I6L } \\
\hline & QFN & GIL & QKN & GIL & QLN & GIL \\
\hline 0 & -25.90 & -24.37 & -23.11 & -38.17 & -13.22 & -13.48 \\
\hline 10 & -27.09 & -7.73 & -14.71 & -6.31 & -39.03 & -3.94 \\
\hline 20 & -9.17 & - & -26.47 & - & -15.57 & - \\
\hline 30 & -11.09 & - & -23.83 & - & -12.87 & - \\
\hline 40 & -11.29 & - & -14.87 & - & -9.097 & - \\
\hline
\end{tabular}

The quantum-chemical calculations showed that the most energeticaly favorable conformation of ThT corresponds to the angles $\varphi=37^{\circ}, 145^{\circ}, 217^{\circ}, 325^{\circ}$. These states are separated by rather low $\left(700-2000 \mathrm{~cm}^{-1}\right.$, depending on a calculation method) energy barriers at $\varphi=90^{\circ}, 180^{\circ}$. In addition, each of the structural segments carries different partial charge for various values of $\varphi$. Thus, both photon excitation and the change of the torsion angle $\varphi$ lead to the redistribution of the electron density between the segment I and segments II + III of the ThT molecule [12].

The molecular docking analysis showed that in the untwisted amyloid fibrils (twisting angle equals $0^{\circ}$ ) there are two preferable binding sites for ThT - the grooves, embracing the the residues GIL and QIN, with the binding energies $\sim-25 \mathrm{kcal} / \mathrm{mol}$ and $\sim-21 \mathrm{kcal} / \mathrm{mol}$, respectively (Table). In turn, in the fibrils with twisting angles $10,20,30$ and $40^{\circ}$, ThT tends to locate within QIN groove. For amyloid fibril of twisted configuration, the curvature at any point is given by:

$$
\kappa=\frac{d}{d^{2}+(P / 2 \pi)^{2}},
$$

where $P$ is a pitch, $d$ is a distance from the center of twisting ribbon. This equation assumes that in the center of the fibril (where $d=0$ ), the curvature of the protein fibrillar aggregate equals to zero. These considerations point to the scenario, according to which ThT molecule prefers the binding site for the minimal curvature. The free energies of ThTfibril association for every protein polymorph are summarized in Table. The obtained results strongly suggest that curvature effects play crucial role in determining the mode of ThT interactions with the twisted fibrillar assemblies. To verify this assumption, we examined the association of ThT with several mutants of K-peptide. The mutations involved 
the substitution of nonpolar isoleucine residue by the animo acids with different physicochemical properties - positively charged lysine, negatively charged glutamic acid, nonpolar leucine and aromatic phenylalanine (I6K, I6E, I6L, I6F). The comparison of the molecular docking results shows that the above mutations do not markedly affect ThT - fibril binding mode. For each of the examined fibrillar configurations ThT prefers the central groove for where the curvature of the fibril is minimal. Obviously, the chemical nature of the amino acid residues constituting the groove plays a less important role in the process of ThT - fibril association.

\section{Molecular dynamics simulations}

In order to obtain a more detailed information about ThT association with amyloid fibrils we performed the molecular dynamics simulation of ThT - fibril complexes. The complex of ThT with the amyloid fibrils constructed from wild-type K-peptide in untwisted configuration was chosen as an input structure for simulation. The initial structure of ThT - fibril complex is represented in Fig. 4A. As illustrated in Fig. 4B, the molecular dynamics simulations over $10 \mathrm{~ns}$ led to the structural modifications of the dye-protein complex. Specifically, it is clearly seen that the fibril changes its initial conformation to the twisted and slightly bended configuration. Along with this, ThT molecule was moved from its initial binding site to the edge of the fibril.

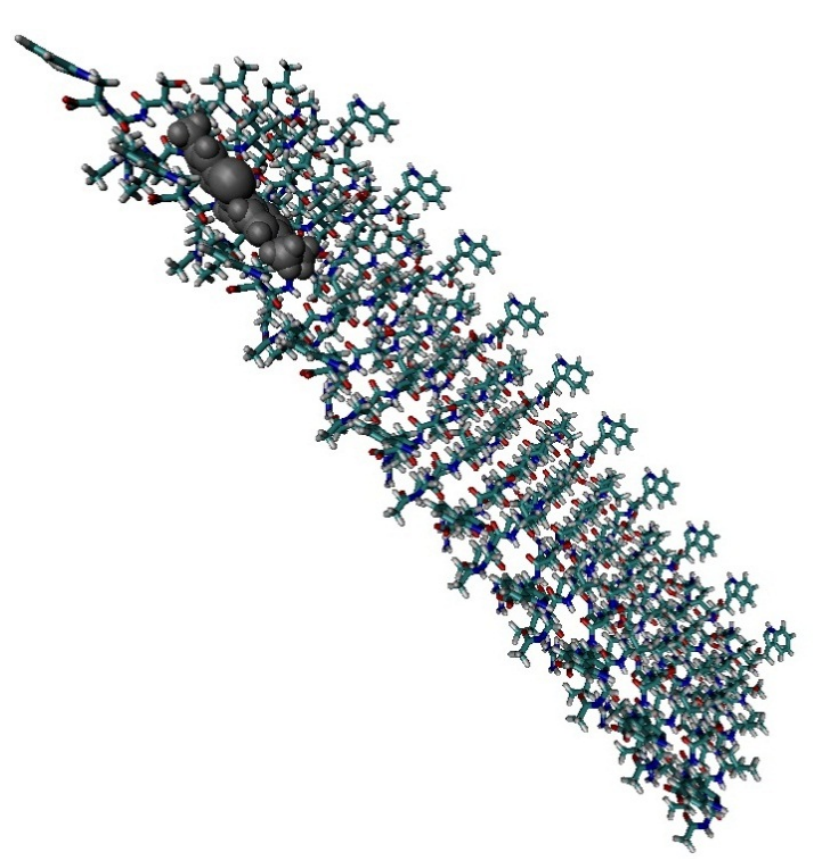

A

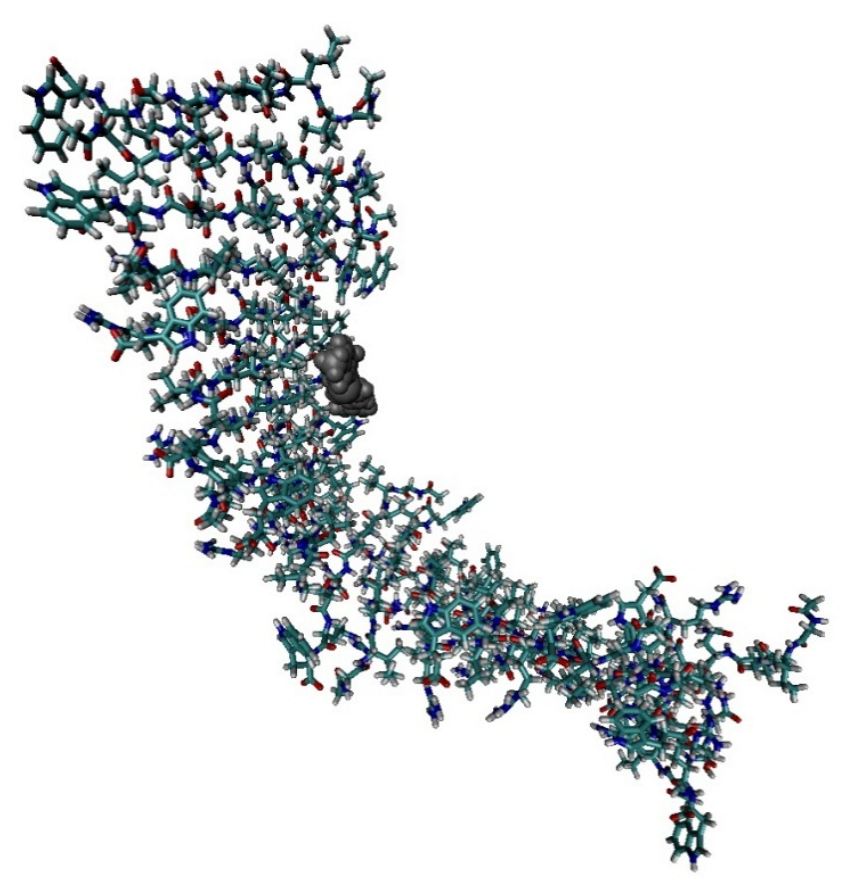

B

Fig. 4. ThT-fibril complex before (A) and after (B) the MD simulation run

The distortion of fibril can be explained by the hydrophobic interaction between the non-polar side chains.

The observed twisting and bending of the fibril structure may arise from the tendency of the fibril to minimize the unfavorable contacts of nonpolar amino acid residues with the solvent. Such kind of structural rearrangement is accompanied by the increase of fibril curvature. Since the molecular docking results showed that ThT prefers the regions with minimal curvature, one may suggest that the twisting and bending of the fibril occurring during the MD simulation reduce the dye affinity for the fibrillar assemblies, which manifests itself in the relocation of ThT molecule closer to the fibril edge. However, this assumption requires further verification.

\section{CONCLUSIONS}

1) Based on different computational approaches (ABALONE, PatchDock, FireDock and CreateFibril), the twisted ribbon fibrils from the K-peptide, constituting the core of amyloid fibrils of hen egg white lysozyme, have been designed.

2) Using the molecular docking method the complexes of Thioflavin $T$ with the K-peptide fibrillar polymorphs differing in their twisting angles have been analyzed and the preferable sites of dye binding have been identified. It was shown that the curvature effects rather than amino acid composition of the grooves determine the preference of Thioflavin $\mathrm{T}$ to the central region of the fibril.

3) The molecular dynamics simulation of Thioflavin $\mathrm{T}$ - fibril complexes over $10 \mathrm{~ns}$ revealed the structural rearrangement of the untwisted fibril towards the twisted and slightly bended configuration, coupled with the relocation of the dye molecule closer to the fibril edge in the course of simulation. 


\section{REFERENCES}

1. Pham C.L.L., Kwan A.H., Sunde M. Functional amyloid: widespread in nature, diverse in purpose // Essays Biochem. - 2014. Vol. 56. - P. 207-219.

2. Tokunaga Y., Sakakibara Y., Kamada Y., Watanabe K., Sugimoto Y. Analysis of core region from egg white lysozyme forming amyloid fibrils // Int. J. Biol. Sci. - 2013. - Vol. 9. - P. 219-227.

3. Aggeli A., Nyrkova I.A., Bell M., Harding R., Carrick L., McLeish T. C. B., Semenov A. N., Boden N. Hierarchical selfassembly of chiral rod-like molecules as a model for peptide $\beta$-sheet tapes, ribbons, fibrils, and fibers // Proc. Natl. Acad. Sci. USA. - 2001. - Vol. 98. - P. 11857-11862.

4. Adamcik J., Mezzenga R. Adjustable twisting periodic pitch of amyloid fibrils // Soft Matter. - 2011. - Vol. 7. - P. 5437-5443.

5. Nelson R., Eisenberg D. Recent atomic models of amyloid fibril structure // Curr. Opinion in Struct. Bio. - 2006. - Vol. 16. P. 260-265.

6. Schneidman-Duhovny D., Inbar Y., Nussinov R., Wolfson H.J. PatchDock and SymmDock: servers for rigid and symmetric docking // Nuc. Acids Res.. - 2005. - Vol. 33. - P. 363-367.

7. Duhovny D., Nussinov R., Wolfson H.J. Efficient Unbound Docking of Rigid Molecules // In Gusfield et al., Ed. Proceedings of the 2'nd Workshop on Algorithms in Bioinformatics (WABI), pp. 185-200, Springer Verlag, 2002

8. Andrusier N., Nussinov R., Wolfson H.J. FireDock: Fast interaction refinement in molecular docking // Proteins. - 2007. Vol. 69. - P. 139-159.

9. Felice F.G., Vieira M.N.N., Meirelles M.N.L., Morozova-roche L.A., Dobson C.M., Ferreira S.T. Formation of amyloid aggregates from human lysozyme and its disease-associated variants using hydrostatic pressure // FASEB J. - 2004. Vol. 18. - P. 1099-1101.

10. Ibrahim H., Thomas U., Pellegrini A. A helix-loop-helix peptide at the upper lip of the active site cleft of lysozyme confers potent antimicrobial activity with membrane permeabilization action // J. Biol. Chem. - 2001. - Vol. 276. - P. 43767-43774.

11. Frare E., Mossuto M., Polverino de Laureto P., Dumoulin M., Dobson C., Fontana A. Identification of the core structure of lysozyme amyloid fibrils by proteolysis // J. Mol. Biol. - 2006. - Vol. 361. - P. 551-561.

12. Voropai E.S., Samtsov M.P., Kaplevskii K.N., Maskevich A.A., Stepuro V.I., Povarova O.I., Kuznetsova I.M., Turoverov K.K., Fink A.L., Uverskiid V.N. Spectral properties of thioflavin T and its complexes with amyloid fibrils // J. of App. Spectroscopy. - 2003. - Vol. 70(6). - P. 868-874.

13. Stsiapura V.I., Maskevich A.A., Kuzmitsky V.A., Turoverov K.K., Kuznetsova I.M. Computational study of thioflavin T torsional relaxation in the excited state // J. Phys. Chem. - 2007. - Vol. 111. - P. 4829-4835. 